\title{
D-Amphetamine and Antipsychotic Drug Effects on Latent Inhibition in Mice Lacking Dopamine $\mathrm{D}_{2}$ Receptors
}

\author{
C Bay-Richter, ${ }^{1,5}$, MJ O'Callaghan ',5, N Mathur', CMP O'Tuathaigh' ${ }^{2}$, DM Heery ${ }^{3}$, KCF Fone $^{4}$, \\ JL Waddington ${ }^{2}$ and PM Moran*, I \\ 'School of Psychology, University of Nottingham, Nottingham, UK; ${ }^{2}$ Molecular and Cellular Therapeutics, Royal College of Surgeons in Ireland, \\ St Stephens Green, Dublin, Ireland; ${ }^{3}$ School of Pharmacy, Centre for Biomolecular Sciences, University of Nottingham, Nottingham, UK; ${ }^{4}$ School of \\ Biomedical Sciences, University of Nottingham, Nottingham, UK
}

\begin{abstract}
Drugs that induce psychosis, such as D-amphetamine (AMP), and those that alleviate it, such as antipsychotics, are suggested to exert behavioral effects via dopamine receptor $D_{2}\left(D_{2}\right)$. All antipsychotic drugs are $D_{2}$ antagonists, but $D_{2}$ antagonism underlies the severe and debilitating side effects of these drugs; it is therefore important to know whether $D_{2}$ is necessary for their behavioral effects. Using $D_{2}$-null mice $\left(\operatorname{Drd}_{2}-/-\right)$, we first investigated whether $D_{2}$ is required for AMP disruption of latent inhibition (LI). $L I$ is a process of learning to ignore irrelevant stimuli. Disruption of LI by AMP models impaired attention and abnormal salience allocation consequent to dysregulated dopamine relevant to schizophrenia. AMP disruption of LI was seen in both wild-type (WT) and Drd $2-1-$. This was in contrast to AMP-induced locomotor hyperactivity, which was reduced in $\operatorname{Drd}_{2}-$ / - . AMP disruption of LI was attenuated in mice lacking dopamine receptor $D_{1}(\operatorname{Drd},-1-)$, suggesting that $D_{1}$ may play a role in AMP disruption of LI. Further supporting this possibility, we found that D, antagonist SKF83566 attenuated AMP disruption of LI in WT. Remarkably, both haloperidol and clozapine attenuated AMP disruption of $\mathrm{LI}$ in $\mathrm{Drd}_{2}-/$ - This demonstrates that antipsychotic drugs can attenuate AMP disruption of learning to ignore irrelevant stimuli in the absence of $D_{2}$ receptors. Data suggest that $D_{2}$ is not essential either for $A M P$ to disrupt or for antipsychotic drugs to reverse AMP disruption of learning to ignore irrelevant stimuli and further that $D_{1}$ merits investigation in the mediation of AMP disruption of these processes.
\end{abstract}

Neuropsychopharmacology (2013) 38, I5 I2-1520; doi:I0.1038/npp.20 I3.50; published online 27 March 2013

Keywords: antipsychotics; D-amphetamine; dopamine $D_{1}$ receptor; dopamine $D_{2}$ receptor; latent inhibition; mice

\section{INTRODUCTION}

Dopamine (DA) receptor $\mathrm{D}_{2}\left(\mathrm{D}_{2}\right)$ blockade is common to all antipsychotic drugs and correlates most closely with clinical efficacy (Howes et al, 2009; Meltzer et al, 1989; Seeman et al, 1976). Antipsychotics, however, have affinities for multiple neurotransmitter and peptide receptors, and it is still unknown whether $\mathrm{D}_{2}$ is essential for their behavioral effects. There is a therapeutic imperative to establish whether activity at $\mathrm{D}_{2}$ is obligatory for antipsychotic drug action, as $\mathrm{D}_{2}$ blockade is also associated with extrapyramidal motor symptoms and tardive dyskinesia, which limit compliance (Fleischhacker et al, 1994; Kapur et al, 2000). There is pharmacological evidence to challenge the view that action at $\mathrm{D}_{2}$ may be solely responsible for antipsychotic drug effects. Newer or 'atypical' antipsychotics such as clozapine, while having equivalent clinical efficacy to older

* Correspondence: Dr PM Moran, School of Psychology, University of Nottingham, University Park, Nottingham NG7 2RD, UK, Tel: +44 II5 95।5312, Fax: +44 II5 95।5324,

E-mail: paula.moran@nottingham.ac.uk

${ }^{5}$ The first two authors contributed equally to this work.

Received 9 November 2012; revised 14 February 2013; accepted 14 February 2013; accepted article preview online 19 February 2013 'typical' drugs such as haloperidol, have affinity for multiple monoamine and peptide receptors (Meltzer et al, 1989). The therapeutic efficacy of 'atypical' antipsychotics can occur at doses that produce much lower occupancy of $\mathrm{D}_{2}$ than typical antipsychotics, although this may be explained in terms of faster rate of dissociation from the receptor (Kapur and Seeman, 2001). For the atypical antipsychotics clozapine and quetiapine, no correlation is found between $\mathrm{D}_{2}$ occupancy and reduction in clinical scores (Yilmaz et al, 2012). There is also dissociation between the motor side effects and clinical efficacy of antipsychotic drugs, despite both being presumed to be mediated by $\mathrm{D}_{2}$ (Natesan et al, 2006). New putative therapies such as metabotropic glutamate receptor agonists intended to circumvent $\mathrm{D}_{2}$ interaction may indirectly interact with $\mathrm{D}_{2}$ (Patil et al, 2007; Seeman and Guan, 2009). The broad pharmacological profile of antipsychotics makes it difficult to study the functional role of individual receptors in specific behavioral effects using drugs and no specific $\mathrm{D}_{2}$ antagonists exist. Here, we used a null mouse approach to investigate whether $D_{2}$ is necessary for antipsychotic drugs to modify salience allocation processes disrupted by D-amphetamine (AMP), tested using the learning phenomenon of latent inhibition (LI).

Symptoms of schizophrenia such as hallucinations and delusions have been suggested to reflect disruption in 
processes that allocate attention or salience to features of the environment. This is considered to be consequent to dysregulated DA transmission and to be remediated by antipsychotic drugs, presumed to be via $\mathrm{D}_{2}$ blockade, although this remains unknown (Gray et al, 1991; Kapur et al, 2005; Howes et al, 2009). LI is widely used in animal models of schizophrenia as an index of the mechanism through which salience or associability (attention to and readiness to form associations) is conferred on stimuli on the basis of how much experience the animal has had of them (Lubow, 2005; Weiner and Arad, 2009). LI is demonstrated experimentally as reduced learning of a conditioned stimulus (CS)-unconditioned stimulus (US) association in a group pre-exposed to that stimulus without reinforcement (pre-exposed, PE) compared with a group without such pre-exposure (non-pre-exposed, NPE). Many, although not all, studies show that patients with schizophrenia display abnormalities in LI, which may depend on the stage of illness (Weiner and Arad, 2009). In rats and humans, antipsychotic drugs such as haloperidol and clozapine potentiate low LI (Moser et al, 2000; Weiner, 2003; Weiner and Arad, 2009). On the other hand, psychotomimetic drugs that induce psychosis, such as AMP that inter alia increase DA release, disrupt LI. Antipsychotic drugs attenuate this disruption in humans, rats, and mice (Chang et al, 2007; Gray et al, 1992; Moser et al, 2000; Weiner, 2003).

Experiments using $\mathrm{D}_{2}$-null mice $\left(\operatorname{Drd}_{2}-/-\right)$ mice suggest that $D_{2}$ is essential for the behavioral and neural effects of AMP, such as methamphetamine hyperactivity, disruption of prepulse inhibition of the acoustic startle response, and DA release (Boulay et al, 1999; Kelly et al, 1998; Schmitz et al, 2001). It is unknown whether $\mathrm{D}_{2}$ is essential for disruption of LI by AMP. Direct stimulation of $\mathrm{D}_{2}$ by the agonist apomorphine has been shown not to disrupt LI (Lacroix et al, 2000), suggesting that $\mathrm{D}_{2}$ activation does not play a role in LI disruption, but later reports have shown that apomorphine can disrupt LI (Melo et al, 2009; Shao et al, 2010). This study aimed first to investigate whether $\mathrm{D}_{2}$ is essential for AMP-induced disruption of LI. The second aim was to investigate whether $\mathrm{D}_{2}$ is required for antipsychotic drugs to attenuate AMPH disruption of LI, which we found to be intact in $\operatorname{Drd}_{2}-/-$ mice. The third aim was to further determine the mechanism by which AMP disrupts LI and to investigate whether $\mathrm{D}_{1}$ is important for AMP disruption of LI.

\section{MATERIALS AND METHODS}

\section{Animals}

The original F2 hybrid strains were generated as reported previously (Drago et al, 1994; Kelly et al, 1997). Congenic $D_{1}$ and $\mathrm{D}_{2}$ lines were established by repeatedly backcrossing heterozygous mutants to wild-type (WT) C57BL/6 for at least 14 generations; homozygous DA receptor $D_{1}$ $\left(\operatorname{Drd}_{1}-/-\right)$ and $\operatorname{Drd}_{2}-I-$ mice and WT $\left(\operatorname{Drd}_{1}+/+\right.$ and $\operatorname{Drd}_{2}+1+$ mice) littermates were then bred by heterozygous intermatings of congenic heterozygote mutants (Waddington et al, 2005). Male and female $(-I-$ and $+I+$ ) littermates were used at 10-20 weeks of age. In experiments involving SKF83566, C57BL/6 mice were used, which were purchased from Charles River UK (Kent, UK) and Charles River (Wilmington, MA). Mice were housed $1-4$ per cage under a $12 \mathrm{~h}$ light: $12 \mathrm{~h}$ dark cycle (lights on at 0700 hours) and constant temperature $\left(20 \pm 2{ }^{\circ} \mathrm{C}\right)$ and humidity (40-60\%), with food available ad libitum. Mice were subjected to daily water restriction periods of $23 \mathrm{~h}$ throughout LI experiments, with $1 \mathrm{~h}$ free access to water in their home cages after each experimental session. All experiments were carried out in accordance with local and national regulations on animal experimentation, and project license authority under the Animals (Scientific Procedures) Act, UK 1986; UK home Office Project licenses No: 40/2883 and its renewal as $40 / 3501$.

\section{Genotyping}

This was performed by PCR using genomic DNA extracted from ear biopsies, as described previously (Bay-Richter et al, 2009).

\section{Latent Inhibition}

Experiments were carried out in six identical conditioning chambers and the LI protocol was the same as that described previously in detail (Bay-Richter et al, 2009). For further details of the apparatus used, see Supplementary Information. Briefly it consisted of the following:

Water restriction (Days 1-7): Mice were placed on 23-h water restriction 7 days before and throughout the experiment.

Pretraining (Days 8-13): Mice were placed in chambers for $15 \mathrm{~min}$ and the number of licks was recorded.

Pre-exposure (Day 14): Mice were placed in chambers with no water present. They were given 60 presentations of a 5-s 85-dB tone with an interstimulus interval of $15 \mathrm{~s}$ (PE group); NPE control mice were placed in the chambers for the same amount of time but received no tone pre-exposures.

Conditioning (Day 15): Mice were placed in chambers with no water present. After $2 \mathrm{~min}$, two tone-footshock pairings were presented. Each tone was of 5-s duration and followed by a 1 -s $0.38-\mathrm{mA}$ footshock and an intertrial interval of $2.5 \mathrm{~min}$; mice remained in the chamber for 2.5 min following the second shock presentation.

Re-baseline lick training (Days 16 and 17): Mice were placed in chambers for $15 \mathrm{~min}$ and given free access to the water sipper to re-establish licking. Mice that did not complete $>300$ licks continuously were excluded from the experiment and did not continue to the test day (two mice in experiment 1 and two in experiment 2).

Test (Day 18): Mice were placed in chambers with free access to the water sipper. The number of licks was recorded and time taken to complete licks 80-90 (A) and 90-100 (B) recorded. After completion of 90 licks, the tone was presented until the mouse reached lick 100 or $600 \mathrm{~s} \mathrm{had}$ elapsed. A suppression ratio (SR) was calculated according to the formula $\mathrm{A} /(\mathrm{A}+\mathrm{B})$ yielding a scale of 0 to 0.5 . As logarithmic transformation did not normalize data in all experiments, SR was therefore considered the most appropriate measure. 


\section{Spontaneous Locomotor Activity}

This was recorded for $30 \mathrm{~min}$ using videotracking of an open field as described previously (Bay-Richter et al, 2009). For further details of the apparatus used and the procedure, see Supplementary Information.

\section{Experimental Design and Statistics}

Statistics were performed using SPSS (Versions 16 (2007) and 18 (2009); SPSS Chicago, IL). For LI experiments, analysis of variance (ANOVA) was used. Post hoc tests comprised planned $T$-tests with Bonferroni correction for $\alpha$ slippage for genotype, drug treatment group, and NPE $v s$ PE comparisons as appropriate. Data were collapsed across sex as there was no significant effect of sex and no interactions with treatment, exposure, or genotype in any experiment. Experiments in $\operatorname{Dr} d_{1}-/$ - mice were explicitly conducted in females because of baseline sex differences in LI previously identified by us; male and female $D r d_{2}-/$-mice and female $\operatorname{Drd}_{1}-/$-mice show comparable LI, but male $\operatorname{Drd}_{1}-I-$ mice do not show LI; hence, AMP disruption could not be evaluated in the present conditions in males (Bay-Richter et al, 2009). Locomotor activity experiments used split-plot ANOVA with genotype and drug treatment group as between-group factors and 5-min time bin as repeated-measures factor. Post hoc comparisons were performed as described for LI experiments. The $n$ numbers per experiment were: 30 (9F, 21M) $\operatorname{Drd}_{2}+/+$ and 19 (9F, 10M) $\operatorname{Drd}_{2}-I$ - (Figure 1a); 18 (7F, 11M) $\operatorname{Drd}_{2}+I+$ and 12 (6M, 6F) $\operatorname{Drd}_{2}-I-$ (Figure 1b); $16 \operatorname{Drd}_{2}+/+(55 \mathrm{~F}$, $61 \mathrm{M})$ and $127(62 \mathrm{~F}, 65 \mathrm{M}) \operatorname{Drd}_{2}-I-$ (Figure 2); 72F $\operatorname{Drd}_{1}+I+$ and 57F $\operatorname{Drd}_{1}-I-$ (Figure 3a); 46 (23F, 23M) $\operatorname{Drd}_{1}+I+$ and $34(17 \mathrm{~F}, 17 \mathrm{M}) \operatorname{Drd}_{1}-I-$ (Figure 3b); and 138 C57BL/6 (70F, 68M) (Figure 4). In all LI experiments, groups did not differ in their times to complete licks 80-90 (time A) nor were there any effects of sex or interaction between sex and other variables (all $\mathrm{F}$ values $<1$ ). Owing to the large number of experimental groups required to allow simultaneous evaluation of clozapine and haloperidol, and requirement for age, sex, and littermate matching, the experiment in Figure 2 was carried out in four matched cohort replications; there were neither significant effects of cohort on SR nor significant interactions with exposure, drug treatment, or genotype (all $\mathrm{F}$ values $<1.5$ ).

\section{Drugs and Administration}

AMP sulfate (Sigma-Aldrich, Dorset, UK) was dissolved in sterile $0.9 \%(\mathrm{w} / \mathrm{v})$ saline and a dose of $2.5 \mathrm{mg} / \mathrm{kg}$ was used in all experiments. SKF83566 (Tocris, Bristol, UK) was dissolved in $0.9 \% \mathrm{NaCl}$ mixed with a few drops of tartaric acid and buffered to pH 6.5 with $\mathrm{NaOH}$. Doses of 0.01 and $0.1 \mathrm{mg} / \mathrm{kg}$ were used. Haloperidol and clozapine (SigmaAldrich) were dissolved in $25 \mu \mathrm{l}$ glacial acetic acid and buffered to $\mathrm{pH} 6.5$ using $0.1 \mathrm{mM} \mathrm{NaOH}$ before final dilution in sterile $0.9 \%$ saline to appropriate concentrations $(0.1 \mathrm{mg} /$ $\mathrm{kg}$ for haloperidol; $2.5 \mathrm{mg} / \mathrm{kg}$ for clozapine); controls received vehicle to the same injection volumes $(10 \mathrm{ml} / \mathrm{kg})$. Doses of AMP $(2.5 \mathrm{mg} / \mathrm{kg}$, intraperitoneally) and haloperidol ( $0.1 \mathrm{mg} / \mathrm{kg}$, intraperitoneally) were based on previously established dosage for LI in mice (Chang et al, 2007; Meyer
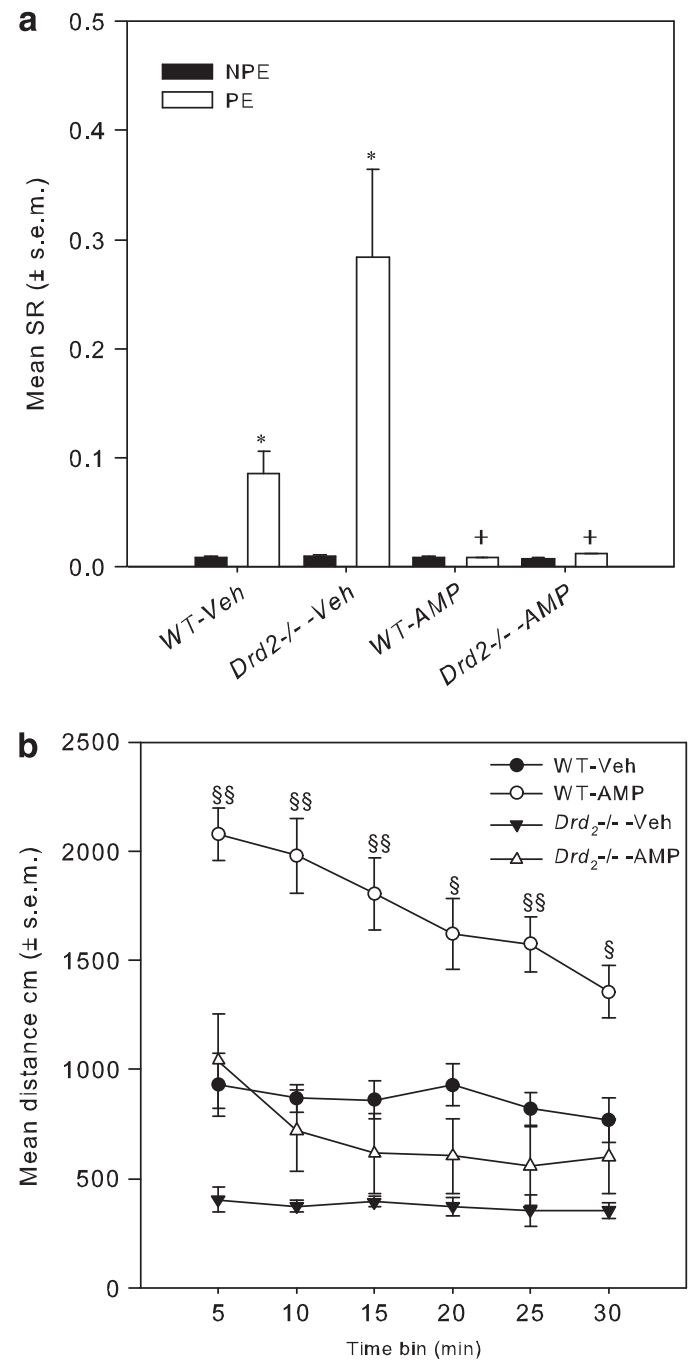

Figure I D-Amphetamine (AMP) disruption of latent inhibition (LI) is similar in wild-type (WT) and $\operatorname{Drd}_{2}-1-$ (a). Vehicle-treated WT (WT-Veh) and vehicle-treated $\operatorname{Drd}_{2}-1-\left(\operatorname{Drd}_{2}-/--V e h\right)$ mice show LI (higher suppression ratio (SR) in pre-exposed (PE) vs non-pre-exposed (NPE)), while D-amphetamine-treated WT (WT-AMP) and D-amphetamine-treated $\operatorname{Drd}_{2}-1$ - (Drd 2 - / - -AMP) mice do not. AMP locomotor hyperactivity seen in WT is blunted in $\operatorname{Drd}_{2}-1-$ mice (b). $* P<0.05 \mathrm{NPE}$ vs $P E$, same genotype and drug; ${ }^{+} P<0.05$ vs vehicle same genotype for $P E ;$ and ${ }^{\S} P<0.05,{ }^{\S} P<<0.00$ I vs vehicle same genotype and time bin. $\operatorname{Drd}_{2}-1-, D_{2}$-null mice.

et al, 2004). The dose of clozapine used was lower than published reports (Lipina et al, 2005), as significant sedation occurred in our hands at published effective doses. For mice receiving AMP in combination with either haloperidol, clozapine, or SKF83566, the drug was administered $5 \mathrm{~min}$ before AMP, with control mice receiving a matched number of vehicle injections. All injections were given intraperitoneal $30 \mathrm{~min}$ before both pre-exposure and conditioning sessions (LI) or both habituation and testing (locomotion). The two injection regimen is based on a number of studies, which show that two injections of $\mathrm{AMPH}$, one before pre-exposure and one before conditioning, are required to disrupt LI (Weiner et al, 1988; although see Young et al, 2005). The same regimen was then maintained to enable direct comparison at the same doses in locomotor activity experiments. 

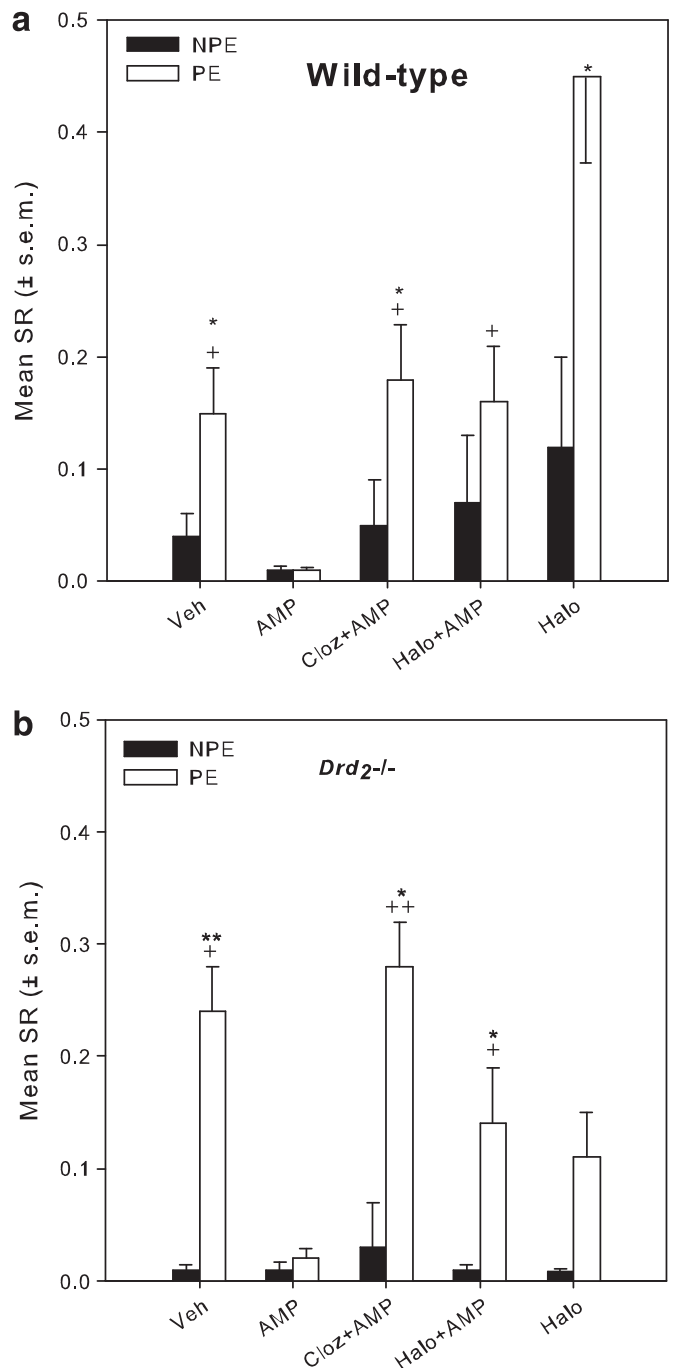

Figure 2 Haloperidol $(\mathrm{Hal})$ and clozapine (Cloz) attenuate disruption of latent inhibition (LI) by D-amphetamine (AMP) in both wild-type (WT; a) and $D_{2}-/$ - mice $\left(\operatorname{Drd}_{2}-/-; b\right)$ ); $P<0.05$, $* * P<0.0$ I, non-pre-exposed (NPE) vs pre-exposed (PE) same genotype and drug; ${ }^{+} P<0.05,{ }^{++}$ $P<0.0$ I vs AMP-PE same genotype. $\operatorname{Drd}_{2}-1-, D_{2}$-null mice.

First experiments investigated effects of AMP on LI and locomotor activity in $\operatorname{Drd}_{2}+/+$ and $\operatorname{Drd}_{2}-/-$. Subsequently, effects of the typical $\mathrm{D}_{2}$ antipsychotic haloperidol and the atypical antipsychotic clozapine on AMP disruption of LI were investigated. To evaluate a potential role for $D_{1}$ in AMP disruption of LI, a series of experiments investigated AMP effects on LI and locomotor activity in $\operatorname{Drd} 1+I+$ and $\operatorname{Drd1}-/-$ and of the D1 antagonist SKF83566 on AMP disruption of LI.

\section{RESULTS}

AMP Reduction of LI in $\operatorname{Drd}_{2}-/$ - Mice

AMP disrupted LI in $\operatorname{Drd}_{2}-/$ - mice (Figure 1a). There was an effect of pre-exposure $\left(\mathrm{F}_{(1,41)}=10.89, P<0.01\right)$, treatment $\left(\mathrm{F}_{(1,41)}=10.78, \quad P<0.01\right)$, and a pre-exposure $\times$ treatment interaction $\left(\mathrm{F}_{(1,41)}=10.20, P<0.01\right)$. There was a significant difference between AMP and vehicle in the PE
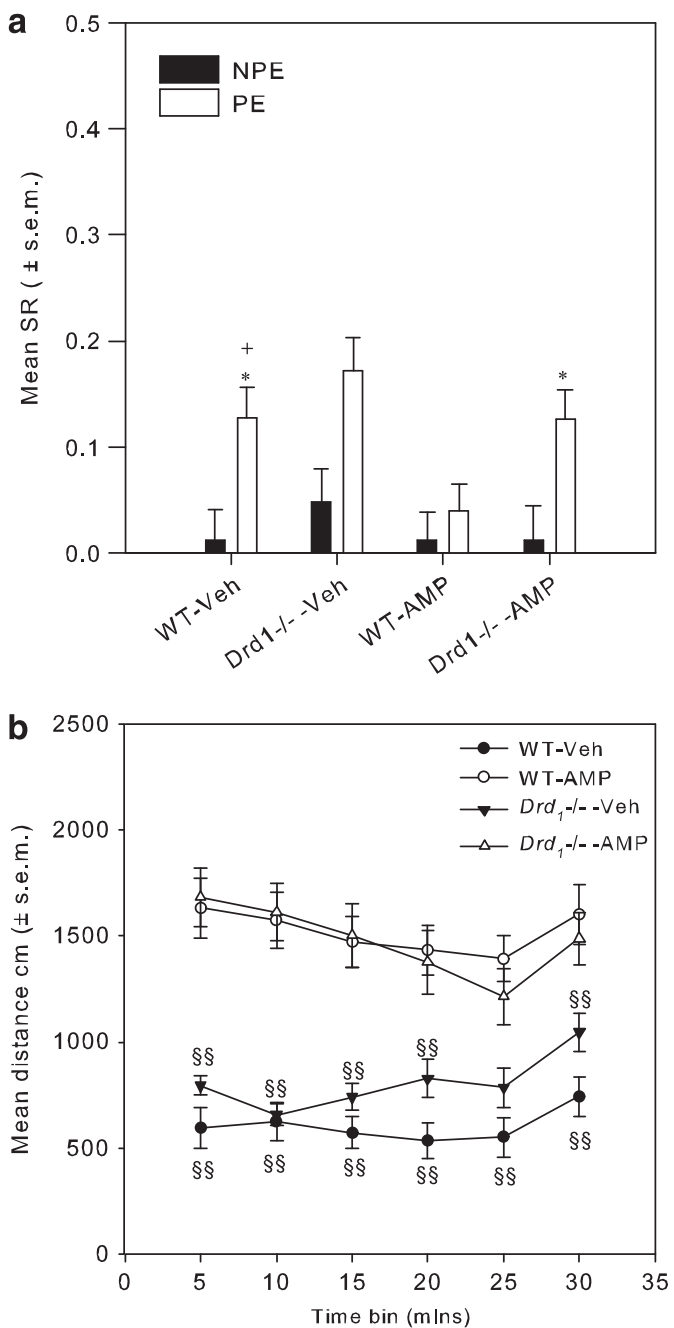

Figure 3 D-Amphetamine (AMP) disruption of latent inhibition (LI) (60 pre-exposed (PE)) is attenuated in Drd, - / - mice (a), but locomotor hyperactivity is not (b). $* P<0.05$ non-pre-exposed (NPE) vs PE same genotype and drug; ${ }^{+} P<0.05$ vs AMP-PE same genotype; ${ }^{\wedge} P<0.05$ vs WT AMP-PE; ${ }^{\$} \S_{P}<0.00$ I vs vehicle same genotype and time bin. Drd, - / $D_{1}$-null mice.

condition $\left(T_{8}=2.749, P<0.05\right)$ and NPE $v s$ PE $\left(T_{8}=2.741\right.$, $P<0.05)$ in $\operatorname{Drd}_{2}-I-$ mice. There was no significant effect of genotype nor interaction between genotype and other factors. In $\operatorname{Drd}_{2}+/+$ mice, there was no significant difference between AMP and vehicle in the PE condition; however, NPE was significantly different from PE condition, indicating $\mathrm{LI}$ in the vehicle $\left(T_{24}=-2.7, P<0.05\right)$ but not the AMP group $\left(T_{21}=0.4\right)$.

\section{AMP Locomotor Hyperactivity in $\operatorname{Drd}_{2}-/$ - Mice}

AMP locomotor hyperactivity was seen in WT mice, but was blunted in $\operatorname{Drd}_{2}-/-$ mice using the same dose and regimen of AMP as described for LI experiments (Figure 1b). There was a significant effect of genotype $\left(\mathrm{F}_{(1,22)}=47.23, P<0.001\right)$, drug treatment $\left(\mathrm{F}_{(1,22)}=33.96\right.$, $P<0.001)$, and a genotype $\times$ drug treatment interaction $\left(\mathrm{F}_{(1,22)}=8.42, P<0.01\right)$. There was a significant effect of time bin $\left(\mathrm{F}_{(5,110)}=13.07, P<0.001\right)$ and an interaction 


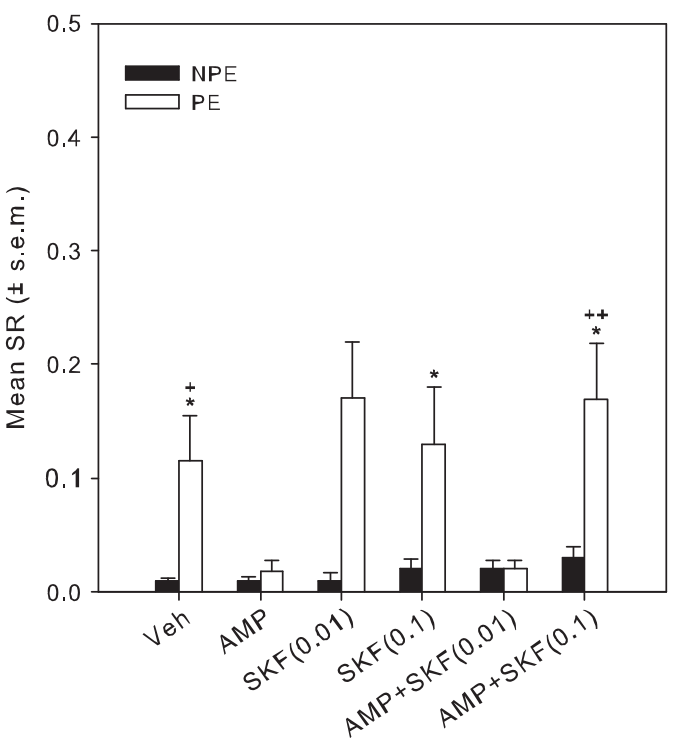

Figure 4 D-Amphetamine (AMP) reduction of latent inhibition (LI) in wild-type (WT) mice is attenuated by pretreatment with SKF83566 at $0.1 \mathrm{mg} / \mathrm{kg}$ but not $0.01 \mathrm{mg} / \mathrm{kg}$. $* P<0.05$ non-pre-exposed (NPE) vs preexposed (PE) same drug; ${ }^{+} P<0.05,{ }^{+}+P<0.0$ I vs AMP-PE.

between time bin and treatment $\left(\mathrm{F}_{(5,110)}=7.46, P<0.001\right)$ but not genotype.

\section{Antipsychotic Drug Effects on LI Reduction by AMP in $D_{2}-I$ - Mice}

AMP disruption of LI in $\operatorname{Drd}_{2}-1$ - mice was attenuated by both drugs tested, haloperidol and clozapine (Figure 2b), demonstrating that clozapine and haloperidol do not require the presence of $\mathrm{D}_{2}$ to attenuate AMP disruption of LI. There were significant effects of pre-exposure $\left.\left(\mathrm{F}_{(1,}, 223\right)=38.10, \quad P<0.001\right)$, treatment $\left(\mathrm{F}_{(4,223)}=5.01\right.$, $P<0.001)$, and an exposure $\times$ treatment interaction $\left(\mathrm{F}\left({ }_{4}\right.\right.$, $223)=2.92, P<0.05)$. There was no significant effect of genotype nor interaction between genotype and other factors $(\mathrm{F}$ 's $<1)$. In WT PE groups, there was a significant difference between AMP vs AMP + haloperidol $\left(T_{21}=-2.68, \quad P<0.05\right)$ and AMP vs AMP + clozapine $\left(T_{19}=-3.43, P<0.05\right)$, and these differences were also seen in $\mathrm{Drd}_{2}-/-$ mice; AMP vs AMP + haloperidol $\left(T_{21}=-2.60, \quad P=0.01\right)$ and AMP $v s$ AMP + clozapine $\left(T_{19}=-3.66, P<0.005\right)$ (Figure $\left.2 \mathrm{~b}\right)$. Vehicle $v s$ haloperidol in PE WT group $\left(T_{19}=2.2\right)$ was not significant. NPE was significantly different from PE group in vehicle$\left(T_{83}=-3.67, \quad P<0.005\right), \quad$ haloperidol- $\quad\left(T_{18}=-2.86\right.$, $P<0.05)$, AMP + haloperidol- $\left(T_{42}=-2.79, P<0.05\right)$, and AMP + clozapine-treated groups $\left(T_{49}=-3.46, P<0.005\right)$ but not in AMP- $\left(T_{41}=-0.5\right)$ treated groups.

\section{AMP Reduction of LI in $\operatorname{Drd}_{1}-/$ - Mice}

We found that AMP disruption of LI is reduced in $\operatorname{Drd}_{1}-I-$ mice compared with WT (Figure 3a). There was a significant effect of drug treatment $\left(\mathrm{F}_{(1,121)}=4.23\right.$, $P<0.05)$, exposure $\left(\mathrm{F}_{(1,121)}=21.00, P<0.001\right)$, and genotype $\left(\mathrm{F}_{(1,121)}=4.05, P<0.05\right)$; the interaction between drug treatment, exposure, and genotype was not significant. There was a significant difference between AMP-WT and AMP-Drd $1-I-$ in PE groups $\left(T_{35}=2.24, P<0.05\right)$, suggesting that AMP effect is moderated in $D_{1}-/-$ mice. There was a significant difference between NPE and PE groups in vehicle- $\left(T_{31}=2.97, P<0.05\right)$ and AMP-treated $\operatorname{Drd}_{1}-I-\left(T_{28}=-2.5, P<0.05\right)$, suggesting LI in these groups but not in AMP-treated $\operatorname{Drd}_{1}+I+$ or vehicletreated $\operatorname{Drd}_{1}-/$ - groups.

\section{AMP Locomotor Hyperactivity in $\operatorname{Drd}_{1}-I-$ Mice}

AMP locomotor hyperactivity was maintained in both WT and $\operatorname{Drd}_{1}-1-$ mice (Figure $3 \mathrm{~b}$ ). There was a significant effect of drug treatment $\left(\mathrm{F}_{(1,76)}=55.50, P<0.001\right)$ but no effect of genotype. There was also a significant effect of time bin $\left(\mathrm{F}_{(5,380)}=13.4, P<0.001\right)$ and an interaction between time bin and drug treatment $\left(\mathrm{F}_{(5,380)}=9.44, P<0.001\right.$.

\section{$D_{1}$ Antagonist SKF83566 Effect on AMP Reduction of $\mathrm{LI}$ in $\mathrm{C} 57 / \mathrm{BL} / 6$ Mice}

Figure 4 shows that pretreatment with SKF83566 at $0.1 \mathrm{mg} / \mathrm{kg}$ but not $0.01 \mathrm{mg} / \mathrm{kg}$ prevented AMP disruption of LI. These data suggest that $\mathrm{D}_{1}$ antagonism can be sufficient to prevent AMP disruption of LI. There was a significant effect of exposure $\left(\mathrm{F}_{(1,116)}=21.38, P<0.001\right)$ and drug treatment $\left(\mathrm{F}_{(5,116)}=2.65, P<0.05\right)$ and a drug treatment $\times$ exposure interaction $\left(\mathrm{F}_{(5,116)}=2.33, P<0.05\right)$. There was a significant difference between $\mathrm{PE}$ groups $\mathrm{AMP}+\mathrm{SKF} 0.1 \mathrm{mg} / \mathrm{kg}$ and AMP $\left(\mathrm{T}_{21}=2.6, P<0.05\right)$. There was a significant difference between NPE and PE conditions in vehicle $\left(T_{21}=-2.37, P<0.05\right), A M P+S K F 0.1 \mathrm{mg} / \mathrm{kg}$ $\left(T_{21}=-2.4, P<0.05\right)$, and SKF $0.01 \mathrm{mg} / \mathrm{kg}\left(T_{22}=-2.7\right.$, $P<0.01)$ groups but not in SKF $0.1 \mathrm{mg} / \mathrm{kg}\left(T_{21}=1.9\right)$ or AMPH-treated group $(T$ s $<0.5)$.

\section{DISCUSSION}

These data show first that AMP disrupts LI in mice lacking $\mathrm{D}_{2}$ receptors, demonstrating that AMP can influence behavior in the absence of $\mathrm{D}_{2}$. This effect of AMP may be specific to processes involved in learning to ignore irrelevant stimuli, as locomotor hyperactivity induced by the same regimen of AMP was blunted in mice lacking $\mathrm{D}_{2}$ receptors. Second, it was found that the $\mathrm{D}_{2}$ receptor is not essential for antipsychotic drugs haloperidol and clozapine to attenuate LI disruption induced by AMP. This has important therapeutic implications as it suggests that it is possible to modulate impaired ability to ignore irrelevant stimuli induced by a hyperdopaminergic state without interaction with $\mathrm{D}_{2}$. Third, AMP disruption of LI was blunted in the absence of $D_{1}$, suggesting that its effects to disrupt LI may require $D_{1}$. Hyperactivity induced by AMP at the same dose was not affected in the absence of $D_{1}$, suggesting dissociation between the effects of AMP on LI and on locomotor activity. AMP disruption of LI was attenuated by the $\mathrm{D}_{1}$ antagonist SKF83566, suggesting further that $D_{1}$ merits further investigation in the mediation of AMP disruption of LI.

Understanding the biological basis of the cognitive effects of AMP and how it affects the selection of information are 
important for the understanding of both its abuse potential and psychotomimetic effects. AMP produces a wide variety of behavioral effects, including psychosis, locomotor hyperactivity, stereotypy, self-administration, and disruption of sensori motor gating in a variety of species (Angrist et al, 1980; Cole, 1978; Hutchison and Swift, 1999; Mansbach et al, 1988; Marriott, 1968; Ralph-Williams et al, 2002). A consistent feature of these behavioral effects of AMP is that they are prevented by antipsychotic drugs that block $D_{2}$, leading to their application as animal models relevant to schizophrenia. Studies in null mice also suggest that $\mathrm{D}_{2}$ plays a crucial role in mediating AMP behavioral effects (Kelly et al, 2008; Ralph et al, 1999). We show that $\mathrm{D}_{2}$ is not essential for AMP to exert its disruptive effect on LI, yet hyperactivity induced by the same dose and regimen of AMP is reduced in the absence of $\mathrm{D}_{2}$. Reduced locomotor activity in $\operatorname{Drd} 2-1-$ mice replicates previous findings using mixed background strains (Kelly et al, 1998). Data suggest that acute stimulatory effects of AMP using this dose and treatment regimen may require $\mathrm{D}_{2}$. Statistical interaction between genotype and treatment suggests that this is distinguishable from baseline reduction in activity in $\operatorname{Drd} 2-/-$ mice. This finding is consistent with evidence showing reduced acute stimulatory effects of methamphetamine in Drd2 - I- mice (Kelly et al, 2008).

Preserved AMP disruption of LI in $\operatorname{Drd}_{2}-I_{-}$is consistent with pharmacological studies indicating no effect of direct $\mathrm{D}_{2}$ agonist apomorphine on LI in rats (eg Broersen et al, 1999, Lacroix et al, 2000). It is notable that in some cases where LI has been disrupted by apomorphine, it is NPE disruption that produced the loss of LI, making effects on LI per se difficult to interpret (eg Melo et al, 2009, Shao et al, 2010).

As AMP acts via presynaptic mechanisms to increase the release of a number of neurotransmitters, including noradrenaline and serotonin, as well as DA, it is possible that its primary DAergic mechanism is devolved to a different mechanism in compensation for developmental absence of $\mathrm{D}_{2}$ in $\operatorname{Drd}_{2}-1-$ mice. There is electrophysiological evidence that firing of DA neurons induced by AMP in the ventral tegmental area switches to a noradrenergic mechanism in the pharmacological absence of $\mathrm{D}_{2}$, that is, in the presence of a $\mathrm{D}_{2}$ antagonist (Cohen and Lipinski, 1986; Shi et al, 2000). Most antipsychotic drugs have affinity at the noradrenaline $\alpha 1$ receptor (Cohen and Lipinski, 1986) as well as $\mathrm{D}_{2}$ and other $\mathrm{DA}$ receptor subtypes, making action through noradrenergic modulation one possible mechanism.

Remarkably, we found that AMP disruption of LI is attenuated by haloperidol and clozapine and does not require the presence of $\mathrm{D}_{2}$. This surprising outcome suggests that attenuation of AMP-induced abnormal salience allocation by antipsychotic drugs can occur in the absence of $\mathrm{D}_{2}$. There are a number of possible candidate biological mechanisms. Drugs such as $5-\mathrm{HT} 22_{\mathrm{A}}$ receptor antagonists have been shown to reverse AMP disruption of LI in rats (Weiner and Arad, 2009); 5-HT2 ${ }_{\mathrm{A}}$ antagonism is a putative feature of 'atypical' antipsychotics and polymorphisms in $5-H T 2_{A}$ genes have been reported in schizophrenia (Maier et al, 2008; Miyamoto et al, 2005). It is worth noting that $5-\mathrm{HT} 2 \mathrm{~A}$ receptors modulate activated but not basal mesolimbic DA function (Schmidt and Fadayel, 1996;
Schmidt et al, 1995). However, while clozapine has significant affinity for $5-\mathrm{HT} 2 \mathrm{~A}$ receptors, haloperidol does not, particularly at the dose used in this study. Interaction with the cholinergic system is also a possible mechanism. Muscarinic receptor M4 agonists have been suggested to have antipsychotic potential (Shekhar et al, 2008; Dencker et al, 2011) and have been shown to reverse AMP disruption of LI (Barak and Weiner, 2011). Abnormal glutamatergic neurotransmission, particularly at $N$-methyl-D-aspartate (NMDA)-type glutamate receptors, has also been implicated in schizophrenia (Olney et al, 1999). NMDA receptors are regulated by the amino-acid glycine and drugs that interact with transporters for glycine (GlyT1) may have antipsychotic potential (Javitt, 2012). The GlyT1inhibitor SSR 103800 has furthermore been shown to reduce AMP disruption of LI (Black et al, 2009). The mechanism of the $\mathrm{D}_{2}$-independent action of these drugs has yet to be identified; however, AMP-disrupted LI in $\operatorname{Drd}_{2}-/-$ mice may be of use as a novel model system to identify $\mathrm{D}_{2}$ independent effects of these drugs. Their identification could suggest neural strategies to remediate hyperdopaminergia-related disruption in a behaviorally specific manner without interaction with $\mathrm{D}_{2}$.

One interpretation of these findings is that AMP effects in $\operatorname{Drd}_{2}-I-$ mice differ from AMP effects in APD-treated mice, broadly suggesting dissociation between pharmacological and genetic manipulations of $\mathrm{D}_{2}$ in the presence of AMP. We have shown previously that in the absence of AMP both potentiate low levels of LI and effects on locomotor activity are consistent, indicating that this dissociation is not a general phenomenon or even specific for LI (Moser et al, 2000; Bay-Richter et al, 2009). One possible explanation is that if AMP interacts with $D_{1}$ to disrupt LI as later experiments suggest, then the $D_{1}$ antagonist action of APD would reverse AMP disruption of LI by pharmacological antagonism. This would not be seen in $\operatorname{Drd}_{2}-/-$; hence, a dissociation would be found. It is also possible that $\operatorname{Drd}_{2}-I-$ mice differ in metabolism or neural activity consequent to developmental absence of $\operatorname{Drd}_{2}$ and this becomes unmasked in the presence of AMP. We cannot determine from this study whether that is the case or not, but this possibility does not alter the conclusion from the study that $D_{2}$ is not essential for AMP disruption of LI.

Our findings indicate an attenuation of AMP disruption of LI in female $\operatorname{Drd} d_{1}-/-$ mice. This is consistent with the observation that the diverse pharmacological actions of psychotomimetic drugs, such as AMP, LSD, and PCP, include effects on $\mathrm{D}_{1}$-mediated function (Watts et al, 1995). Supporting a role for $\operatorname{Drd}_{1}-/-$, we showed that SKF83566 attenuated the effects of AMP on LI. In contrast, we show that AMP effects on locomotor activity are not reduced in $\operatorname{Drd}_{1}-I-$ mice. AMP hyperlocomotor activity has previously been shown to be blunted in $\operatorname{Drd}_{1}-1-$ mice on mixed background strains following acute and repeated administration (Xu et al, 2000; Crawford et al, 1997). We cannot determine whether this difference is due to background strain difference, dose, or dosing regimen of AMP. However, intact locomotor stimulation by AMP in $\operatorname{Drd}_{1}-1-$ mice is clearly dissociable from both attenuated locomotor stimulation seen in their $\operatorname{Drd}_{2}-/-$ counterparts and attenuated disruption of LI in $\operatorname{Drd}_{1}-/-$ female mice 
using the same dose and regimen of AMP. There is a possibility that this finding is sex-specific as male $\operatorname{Drd}_{1}-I-$ could not be evaluated in these conditions, as they do not show robust LI. Recently, it has been shown in male rat studies that the $\mathrm{D} 1$ antagonist $\mathrm{SCH} 23390$ can reverse AMP effects on LI (Nelson et al, 2012), suggesting that these effects may not be specific to mice or females. Previous rat studies have shown that LI disruption by nicotine is also reversed by $\mathrm{D}_{1}$ antagonists. Nicotine (like AMP) is thought to disrupt LI via mesolimbic DA release and is reversed by antipsychotic drugs (Joseph et al, 1993; Moran et al, 1996; Young et al, 2005). Taken together with the present data, we suggest that the role of $D_{1}$ in drug effects to disrupt and potentially improve salience allocation merits further investigation. It has been suggested that $D_{1}$ antagonism may be important for the behavioral effects of antipsychotics and may be secondary to $\mathrm{D}_{2}$ antagonism (Josselyn et al, 1997; Miller, 1990, 2009). A potential role for $\mathrm{D}_{1}$ in AMP disruption of LI is consistent with studies in rats implicating $\mathrm{D}_{1}$ in overshadowing, a related measure of salience allocation, other behavioral effects of AMP in other species, as well as a more general role for midbrain $D_{1}$ in attentional accuracy (Liu et al, 2010, 2011; O'Tuathaigh and Moran, 2002; Zelikowsky and Fanselow, 2010).

Translation of the outcome of experiments using animal model systems to human psychosis and its treatment must include the caveat of species and environmental differences from the human condition. In these studies, mice were water restricted; there is a possibility that this may be important for demonstration of the effects we have shown. In rats, it has been shown that drinking in water-restricted rats can increase midbrain DA release (Young et al, 1992). It is possible that cross-sensitization may have occurred between effects of water restriction and AMP effects on DA release in key brain regions such as the nucleus accumbens. Sensitization of the locomotor response induced by AMP has been shown specifically to involve $\mathrm{D}_{1}$ (Vezina, 1996); further experiments would be required to test this possibility.

\section{CONCLUSION}

We have demonstrated the principle that AMP, clozapine, and haloperidol can exert behavioral effects in the absence of $\mathrm{D}_{2}$ in mice. These $\mathrm{D}_{2}$-independent effects may be behaviorally specific to the process of learning to ignore irrelevant stimuli and allocating salience appropriately as measured in LI. $D_{1}$ merits further investigation in the mediation of these effects. Identification of this $\mathrm{D}_{2}$-independent mechanism may constitute a novel behavior-driven approach to identify existing and candidate antipsychotic drug actions that are behaviorally specific and independent of $\mathrm{D}_{2}$.

\section{ACKNOWLEDGEMENTS}

This work was supported by The Wellcome Trust, UK (WT0845921Z) and Science Foundation Ireland Principal Investigator Grant (07/IN.1/B960). CBR and NM were funded by studentships from the School of Psychology, University of Nottingham, UK. $D R D_{1}-/-$ mice were bred with the kind permission of Dr John Drago (University of Melbourne, Melbourne, VIC, Australia); $D_{2}-I-$ mice were bred with the kind permission of Dr Malcolm Low (Oregon Health and Science University, Portland, OR). CBR is now at the Department of Psychoneuroimmunology, Section for Psychiatry Department of Clinical Sciences, Lund, Sweden. MJO'C is now at Cerca Insights Sdn Bhd, Northern Corridor Technology Development Center (NTDC), Penang, Malaysia.

\section{DISCLOSURE}

The authors declare no conflict of interest.

\section{REFERENCES}

Angrist B, Rotrosen J, Gershon S (1980). Responses to apomorphine, amphetamine, and neuroleptics in schizophrenic subjects. Psychopharmacology 67: 31-38.

Barak S, Weiner I (2011). The M/M4 preferring agonist xanomeline reverses amphetamine-, MK801- and scopolamine-induced abnormalities of latent inhibition: putative efficacy against positive, negative and cognitive symptoms in schizophrenia.. Int J Neuropsychopharmacol 14: 1233-1246.

Bay-Richter C, O’Tuathaigh CMP, O’Sullivan G, Heery DM, Waddington JL, Moran PM (2009). Enhanced latent inhibition in dopamine receptor-deficient mice is sex-specific for the D-1 but not D-2 receptor subtype: implications for antipsychotic drug action. Int J Neuropsychopharmacol 12: 403-414.

Black M, Varty G, Aarad M, Barak S, DeLevie A, Boulay D et al (2009). Procognitive and antipsychotic efficacy of glycine transport 1 inhibitors (GlyT1) in acute and neurodevelopmental models of schizophrenia: latent inhibition studies in the rat. Psychopharmacology 202: 385-396.

Boulay D, Depoortere R, Perrault G, Borrelli E, Sanger DJ (1999). Dopamine D-2 receptor knock-out mice are insensitive to the hypolocomotor and hypothermic effects of dopamine D-2/D-3 receptor agonists. Neuropharmacology 38: 1389-1396.

Broersen LM, Feldon J, Weiner I (1999). Dissociative effects of apomorphine infusions into the medial prefrontal cortex of rats on latent inhibition, prepulse inhibition and amphetamineinduced locomotion. Neuroscience 94: 39-46.

Chang T, Meyer U, Feldon J, Yee BK (2007). Disruption of the US pre-exposure effect and latent inhibition in two-way active avoidance by systemic amphetamine in C57BL/6 mice. Psychopharmacology 191: 211-221.

Cohen BM, Lipinski JF (1986). In vivo potencies of antipsychoticdrugs in blocking alpha-1 noradrenergic and dopamine D2 receptors-implications for drug mechanisms of action. Life Sci 39: $2571-2580$.

Cole SO (1978). Brain mechanisms of amphetamine-induced anorexia, locomotion, and stereotypy-review. Neurosci Biobehav Rev 2: 89-100.

Crawford CA, Drago J, Watson JB, Levine MS (1997). Effects of repeated amphetamine treatment on the locomotor activity of the dopamine D1A-deficient mouse. Neuroreport 8: 2523-2527.

Dencker B, Wortwein G, Weikop P, Jeon J, Thomsen M, Sager TN et al (2011). Involvement of a subpopulation of Neuronal M4 Muscarinic Acetylcholine receptors in the antipsychotic effect of the Muscarinic receptor Agonist Xanomeline. J Neurosci 31: 5905-5908.

Drago J, Gerfen CR, Lachowicz JE, Steiner H, Hollon TR, Love PE et al (1994). Altered striatal function in a mutant mouse lacking D-1a dopamine-receptors. Proc Natl Acad Sci US A 91: 12564-12568. 
Fleischhacker WW, Meise U, Gunther V, Kurz M (1994). Compliance with antipsychotic drug-treatment-influence of side-effects. Acta Psychiatr Scand 89: 11-15.

Gray JA, Feldon J, Rawlins JNP, Smith AD, Hemsley DR (1991). The neuropsychology of schizophrenia. Behav Brain Sci 14: 1-19.

Gray NS, Hemsley DR, Gray JA (1992). Abolition of latent inhibition in acute, but not chronic, schizophrenics. Neurol Psychiatry Brain Res 1: 83-89.

Howes OD, Egerton A, Allan V, McGuire P, Stokes P, Kapur S (2009). Mechanisms underlying psychosis and antipsychotic treatment response in schizophrenia: insights from PET and SPECT imaging. Curr Pharm Design 15: 2550-2559.

Hutchison KE, Swift R (1999). Effect of $d$-amphetamine on prepulse inhibition of the startle reflex in humans. Psychopharmacology 143: 394-400.

Javitt DC (2012). Glycine transport inhibitors in the treatment of schizophrenia. Handbook Exp Pharmacol 213: 367-399.

Joseph MH, Peters SL, Gray JA (1993). Nicotine blocks latent inhibition in rats-evidence for a critical role of increased functional-activity of dopamine in the mesolimbic system at conditioning rather than preexposure. Psychopharmacology 110: 187-192.

Josselyn SA, Miller R, Beninger RJ (1997). Behavioral effects of clozapine and dopamine receptor subtypes. Neurosci Biobehav Rev 21: 531-558.

Kapur S, Mizrahi R, Li M (2005). From dopamine to salience to psychosis - linking biology, pharmacology and phenomenology of psychosis. Schizophr Res 79: 59-68.

Kapur S, Seeman P (2001). Does fast dissociation from the dopamine D-2 receptor explain the action of atypical antipsychotics?: a new hypothesis. Am J Psychiatry 158: 360-369.

Kapur S, Zipursky R, Jones C, Remington G, Houle S (2000). Relationship between dopamine D-2 occupancy, clinical response, and side effects: a double-blind PET study of first-episode schizophrenia. Am J Psychiatry 157: 514-520.

Kelly MA, Low MJ, Rubinstein M, Phillips TJ (2008). Role of dopamine D1-like receptors in methamphetamine locomotor responses of D2 receptor knockout mice. Genes Brain Behav 7: 568-577.

Kelly MA, Rubinstein M, Asa SL, Zhang G, Saez C, Bunzow JR et al (1997). Pituitary lactotroph hyperplasia and chronic hyperprolactinemia in dopamine D2 receptor-deficient mice. Neuron 19: 103-113.

Kelly MA, Rubinstein M, Phillips TJ, Lessov CN, Burkhart-Kasch S, Zhang G et al (1998). Locomotor activity in D2 dopamine receptor-deficient mice is determined by gene dosage, genetic background, and developmental adaptations. J Neurosci 18: 3470-3479.

Killcross AS, Dickinson A, Robbins TW (1994). Amphetamineinduced disruptions of latent inhibition are reinforcer mediated-implications for animal-models of schizophrenic attentional dysfunction. Psychopharmacology 115: 185-195.

Lacroix L, Broersen LM, Feldon J, Weiner I (2000). Effects of local infusions of dopaminergic drugs into the medial prefrontal cortex of rats on latent inhibition, prepulse inhibition and amphetamine induced activity. Behav Brain Res 107: 111-121.

Lipina T, Labrie V, Weiner I, Roder J (2005). Modulators of the glycine site on NMDA receptors, D-serine and ALX 5407, display similar beneficial effects to clozapine in mouse models of schizophrenia. Psychopharmacology 179: 54-67.

Liu Y, Aragona BJ, Young KA, Dietz DM, Kabbaj M, MazeiRobison $\mathrm{M}$ et al (2010). Nucleus accumbens dopamine mediates amphetamine-induced impairment of social bonding in a monogamous rodent species. Proc Natl Acad Sci USA 107: 1217-1222.

Liu Y, Young KA, Curtis JT, Aragona BJ, Wang ZX (2011). Social bonding decreases the rewarding properties of amphetamine through a dopamine D1 receptor-mediated mechanism. J Neurosci 31: 7960-7966.
Lubow RE (2005). Construct validity of the animal latent inhibition model of selective attention deficits in schizophrenia. Schizophr Bull 31: 139-153.

Maier W, Mossner R, Quednow BB, Wagner M, Hurlemann R (2008). From genes to psychoses and back: the role of the 5HT2 alpha-receptor and prepulse inhibition in schizophrenia. Eur Archiv Psychiatry Clin Neurosci 258: 40-43.

Mansbach RS, Geyer MA, Braff DL (1988). Dopaminergic stimulation disrupts sensorimotor gating in the rat. Psychopharmacology 94: 507-514.

Marriott AS (1968). Effects of amphetamine caffeine and methylphenidate on locomotor activity of rats in an unfamiliar environment. Int J Neuropharmacol 7: 487-48.

Melo LL, Pereira EC, Pagini CH, Coimbra NC, Brandão ML, Ferrari EA (2009). Effects of microinjections of apomorphine and haloperidol into the inferior colliculus on the latent inhibition of the conditioned emotional response. Exp Neurol 216: 16-21.

Meltzer HY, Matsubara S, Lee JC (1989). Classification of typical and atypical antipsychotic-drugs on the basis of dopamine D-1, D-2 and serotonin2 Pki values. J Pharmacol Exp Therap 251: 238-246.

Meyer U, Chang DLT, Feldon J, Yee BK (2004). Expression of the CS- and US-pre-exposure effects in the conditioned taste aversion paradigm and their abolition following systemic amphetamine treatment in C57BL6/J mice. Neuropsychopharmacology 29: 2140-2148.

Miller R (2009). Mechanisms of action of antipsychotic drugs of different classes, refractoriness to therapeutic effects of classical neuroleptics, and individual variation in sensitivity to their actions: PART II. Curr Neuropharmacol 7: 315-330.

Miller R, Wickens JR, Beninger RJ (1990). Dopamine D-1-receptor and D-2-receptor in relation to reward and performance-a case for the D-1-receptor as a primary site of therapeutic action of neuroleptic drugs. Progr Neurobiol 34: 143-183.

Miyamoto S, Duncan GE, Marx CE, Lieberman JA (2005). Treatments for schizophrenia: a critical review of pharmacology and mechanisms of action of antipsychotic drugs. Mol Psychiatr 10: 79-104.

Moran PM, Fischer TR, Hitchcock JM, Moser PC (1996). Effects of clozapine on latent inhibition in the rat. Behav Pharmacol 7: 42-48.

Moser PC, Hitchcock JM, Lister S, Moran PM (2000). The pharmacology of latent inhibition as an animal model of schizophrenia. Brain Res Rev 33: 275-307.

Natesan S, Reckless GE, Nobrega JN, Fletcher PJ, Kapur S (2006). Dissociation between in vivo occupancy and functional antagonism of dopamine D-2 receptors: comparing aripiprazole to other antipsychotics in animal models. Neuropsychopharmacology 31: 1854-1863.

Nelson AJ, Thur KE, Cassaday HJ (2012). Dopamine D1 receptor involvement in latent inhibition and overshadowing. Int $J$ Neuropharmacol 15: 1513-1523.

Olney JW, Newcomer JW, Farber NB (1999). NMDA receptor hypofunction model of schizophrenia. J Psychiatric Res 33: 523-533.

O’Tuathaigh CMP, Moran PM (2002). Evidence for dopamine D-1 receptor involvement in the stimulus selection task: overshadowing in the rat. Psychopharmacology 162: 225-231.

Patil ST, Zhang L, Martenyi F, Lowe SL, Jackson KA, Andreev BV et al (2007). Activation of $\mathrm{mGlu} 2 / 3$ receptors as a new approach to treat schizophrenia: a randomized phase 2 clinical trial. Nat Med 13: 1102-1107.

Ralph RJ, Varty GB, Kelly MA, Wang YM, Caron MG, Rubinstein $M$ et al (1999). The dopamine D-2, but not D-3 or D-4, receptor subtype is essential for the disruption of prepulse inhibition produced by amphetamine in mice. J Neurosci 19: 4627-4633.

Ralph-Williams RJ, Lehmann-Masten V, Otero-Corchon V, Low MJ, Geyer MA (2002). Differential effects of direct and indirect 
dopamine agonists on prepulse inhibition: a study in D1 and D2 receptor knock-out mice. J Neurosci 22: 9604-9611.

Schmidt CJ, Fadayel GM (1996). Regional effects of MK-801 on dopamine release: effects of competitive NMDA or 5-HT2A receptor blockade. J Pharmacol Exp Therap 277: 1541-1549.

Schmidt CJ, Sorensen SM, Kehne JH, Carr AA, Palfreyman MG (1995). The role of 5-Ht2a receptors in antipsychotic activity. Life Sci 56: 2209-2222.

Schmitz Y, Lee CJ, Schmauss C, Gonon F, Sulzer D (2001). Amphetamine distorts stimulation-dependent dopamine overflow: effects on D2 autoreceptors, transporters, and synaptic vesicle stores. J Neurosci 21: 5916-5924.

Seeman P, Guan HC (2009). Glutamate agonist LY404,039 for treating schizophrenia has affinity for the dopamine D2(high) receptor. Synapse 63: 935-939.

Seeman P, Lee T, Chauwong M, Wong K (1976). Antipsychotic drug doses and neuroleptic-dopamine receptors. Nature 261: 717-719.

Shao F, Han X, Li N, Wang W (2010). Adolescent chronic apomorphine treatment impairs latent inhibition and reduces prefrontal cortex mGluR5 receptor expression in adult rats. Eur J Pharmacol 649: 202-205.

Shekhar A, Potter WZ, Lightfoot J, Lienmemann J, Dube S, Mallinckrodt C et al (2008). Selective muscarinic receptor agonist xanomeline as a novel treatment approach for schizophrenia. Am J Psychiatry 165: 1033-1039.

Shi WX, Pun CL, Zhang XX, Jones MD, Bunney BS (2000). Dual effects of D-amphetamine on dopamine neurons mediated by dopamine and nondopamine receptors. J Neurosci 20: 3504-3511.

Vezina P (1996). D1 dopamine receptor activation is necessary for the induction of sensitization by amphetamine in the ventral tegmental area. J Neurosci 16: 2411-2420.

Waddington JL, O'Tuathaigh C, O'Sullivan G, Tomiyama K, Koshikawa N, Croke DT (2005). Phenotypic studies on dopamine receptor subtype and associated signal transduction mutants: insights and challenges from 10 years at the psychopharmacology-molecular biology interface. Psychopharmacology 181: 611-638.
Watts VJ, Lawler CP, Fox DR, Neve KA, Nichols DE, Mailman RB (1995). Lsd and structural analogs-pharmacological evaluation at D-1 dopamine-receptors. Psychopharmacology 118: 401-409.

Weiner I (2003). The 'two-headed' latent inhibition model of schizophrenia: modeling positive and negative symptoms and their treatment. Psychopharmacology 169: 257-297.

Weiner I, Arad M (2009). Using the pharmacology of latent inhibition to model domains of pathology in schizophrenia and their treatment. Behav Brain Res 204: 369-386.

Weiner I, Bernasconi E, Broersen LM, Feldon J (1997). Amphetamine-induced disruption of latent inhibition depends on the nature of the stimulus. Behav Pharmacol 8: 442-457.

Weiner I, Lubow RE, Feldon J (1988). Disruption of latent inhibition by acute administration of low doses of amphetamine. Pharmacol Biochem 30: 871-878.

$\mathrm{Xu}$ M, Guo YH, Vorhees CV, Zhang JH (2000). Behavioral responses to cocaine and amphetamine administration in mice lacking the dopamine D1 receptor. Brain Res 852: 198-207.

Yilmaz Z, Zai CC, Hwang R, Mann S, Arenovich T, Remington G et al (2012). Antipsychotics, dopamine $\mathrm{D}_{2}$ receptor occupancy and clinical improvement in schizophrenia: a meta-analysis. Schizophr Res 140: 214-220.

Young AMJ, Joseph MH, Gray JA (1992). Increased dopamine release in vivo in nucleus accumbens and caudate nucleus of the rat during drinking: a microdialysis study. Neuroscience 48: 871-876.

Young AMJ, Moran PM, Joseph MH (2005). The role of dopamine in conditioning and latent inhibition: What, when, where and how? Neurosci Biobehav Rev 29: 963-976.

Zelikowsky M, Fanselow MS (2010). Opioid regulation of pavlovian overshadowing in fear conditioning. Behav Neurosci 124: 510-519.

This work is licensed under a Creative Commons Attribution-NonCommercial-ShareAlike 3.0 Unported License. To view a copy of this license, visit http:// creativecommons.org/licenses/by-nc-sa/3.0/

Supplementary Information accompanies the paper on the Neuropsychopharmacology website (http://www.nature.com/npp) 